\title{
UCRL-CONF-155471
}

\section{NIF Optical Materials and Fabrication Technologies: An Overview}

J. H. Campbell, R. Hawley-Fedder, C. J. Stolz, J. A. Menapace, M. R. Borden, P. Whitman, J. Yu, M. Runkel, M. Riley, M. Feit, and R. Hackel

SPIE 2004 Photonics West, San Jose, California, January 24-29, 2004

\section{February 23, 2004}


This document was prepared as an account of work sponsored by an agency of the United States Government. Neither the United States Government nor the University of California nor any of their employees, makes any warranty, express or implied, or assumes any legal liability or responsibility for the accuracy, completeness, or usefulness of any information, apparatus, product, or process disclosed, or represents that its use would not infringe privately owned rights. Reference herein to any specific commercial product, process, or service by trade name, trademark, manufacturer, or otherwise, does not necessarily constitute or imply its endorsement, recommendation, or favoring by the United States Government or the University of California. The views and opinions of authors expressed herein do not necessarily state or reflect those of the United States Government or the University of California, and shall not be used for advertising or product endorsement purposes. 


\title{
NIF optical materials and fabrication technologies: An overview
}

\author{
J. H. Campbel1*, R. A. Hawley-Fedder, C. J. Stolz, J. A. Menapace, M. R. Borden, \\ P. K. Whitman, J. Yu, M. Runkel, M. O. Riley, M. D. Feit and R. P. Hackel \\ University of California, Lawrence Livermore National Laboratory, 7000 East Avenue, L-491 \\ Livermore, CA 94550
}

\begin{abstract}
The high-energy/high-power section of the NIF laser system contains 7360 meter-scale optics. Advanced optical materials and fabrication technologies needed to manufacture the NIF optics have been developed and put into production at key vendor sites. Production rates are up to 20 times faster and per-optic costs 5 times lower than could be achieved prior to the NIF. In addition, the optics manufactured for NIF are better than specification giving laser performance better than the design. A suite of custom metrology tools have been designed, built and installed at the vendor sites to verify compliance with NIF optical specifications. A brief description of the NIF optical wavefront specifications for the glass and crystal optics is presented. The wavefront specifications span a continuous range of spatial scale-lengths from $10 \mu \mathrm{m}$ to $0.5 \mathrm{~m}$ (full aperture). We have continued our multi-year research effort to improve the lifetime (i.e. damage resistance) of bulk optical materials, finished optical surfaces and multi-layer dielectric coatings. New methods for post-processing the completed optic to improve the damage resistance have been developed and made operational. This includes laser conditioning of coatings, glass surfaces and bulk KDP and DKDP and well as raster and full aperture defect mapping systems. Research on damage mechanisms continues to drive the development of even better optical materials.
\end{abstract}

\section{INTRODUCTION}

The NIF contains 7360 large aperture optics $(\sim 0.5$ to $1.0 \mathrm{~m})$ making it not only the largest laser but also the largest optical system ever constructed ${ }^{[1]}$. Table 1 summarizes the number and types of optics installed in the NIF's 192beamlines. To manufacture the NIF optics required an extensive optical materials and process development effort that began in 1995. This was followed by several years of activities for design and construction of manufacturing facilities and start-up ("pilot") operation. To accomplish this, LLNL has partnered with a group of well-known optical materials and optics fabrication companies located around the world. At the time of this article (Jan 2004) we are entering our tenth year since the start of the NIF optics effort. More than $40 \%$ of the large-aperture optics required for the NIF have been completed and are in the warehouse ready for installation. Many of the remaining $60 \%$ are in the manufacturing cycle and are on schedule for meeting the NIF project completion.

Table 1. Summary of the number and types of large aperture $(\sim 0.5$ to $1.0 \mathrm{~m})$ optics used on the NIF

\begin{tabular}{|l|c|c|}
\hline \multicolumn{1}{|c|}{ Optic } & Number required & Key material(s) \\
\hline Amplifier slabs & 3072 & Phosphate glass \\
\hline Mirrors and polarizers & 1600 & $\mathrm{HfO}_{2} / \mathrm{SiO}_{2}$ coating on BK-7 \\
\hline Windows and lenses & 1728 & $\mathrm{SiO}_{2}$ \\
\hline Crystals & 576 & $\mathrm{DKDP}^{2} \mathrm{KDP}$ \\
\hline Gratings & 192 & $\mathrm{SiO}_{2}$ \\
\hline Debris shields & 192 & $\mathrm{SiO}_{2}$ \\
\hline \multicolumn{2}{|c|}{ Total: 7360 } \\
\hline
\end{tabular}

*campbell1@1lnl.gov phone (925) 422-6497 


\section{OVERVIEW OF THE NIF OPTICAL LAYOUT}

The optical layout of one of the NIF's 192 identical beamlines is shown schematically in Figure 1. Each beamline contains a series of flashlamp-pumped, Nd-glass amplifiers operating at $1053 \mathrm{~nm}$. These amplifiers are located in two sections in the main laser: the power amplifier, and the multi-pass or main amplifier; these sections respectively contain five and eleven Nd-glass laser slabs per beamline. In total, the 192 beamline NIF contains 3072 such slabs, each weighing about 42 kilogram and measuring $46 \mathrm{~cm} \times 81 \mathrm{~cm} \times 4 \mathrm{~cm}$. The slabs are mounted at Brewster's angle to minimize Fresnel surface reflection losses and to enhance the pump efficiency by the surrounding flashlamps.

A plasma-electrode pockels cell (PEPC) is used in combination with a large-aperture (1-m) polarizer to control the number of passes through the amplifier sections ${ }^{[2-4]}$. The NIF utilizes four passes through the 11-slab-long amplifier section within the main laser cavity, in other words, two round trips. Each of the PEPC apertures contains a 1-cm thick potassium dihydrogen (KDP) plate cut normal to the crystal z-axis. The crystal plate is installed in a vacuum cell between two fused silica windows. Glow-discharge plasmas are ignited in the evacuated spaces on the two faces of the crystal. The plasmas have an electron density low enough not to absorb, reflect or diffract the beam as it passes through the cell yet sufficient to provide the conductivity needed to charge the opposing crystal faces to the switching voltage $(\sim 15 \mathrm{kV})$ in about 100 nanoseconds.

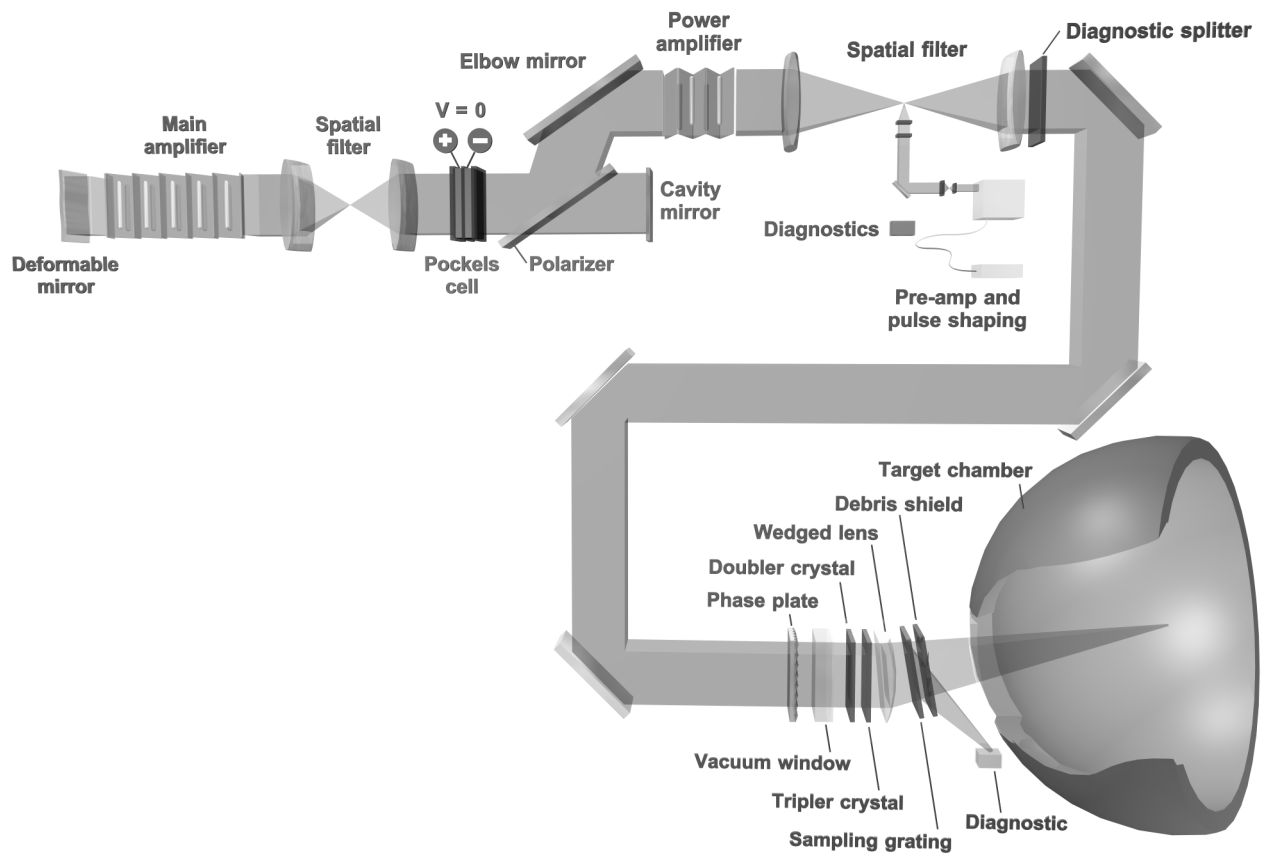

Fig. 1. Schematic representation of the optical layout of one of the 192 identical laser beam-lines that comprise the NIF.

Two large confocal spatial filters (nominally 25 and $60 \mathrm{~m}$ in length) use pinholes as low-pass filters to remove high spatial frequency noise and image relay the propagating beams to the target chamber ${ }^{[1,5]}$. The equi-convex lenses used at both ends of the spatial filters have a slight aspheric correction applied to one side. The lenses are fabricated from fused silica and have back-focal lengths of 11.6 and $29.7 \mathrm{~m}$, respectively, measured to an accuracy of about one part in 10,000.

Multi-layer high-reflectivity dielectric coatings deposited on BK-7 substrates serve as mirrors throughout the NIF. The coating layers are $\mathrm{HfO}_{2} / \mathrm{SiO}_{2}$ deposited by e-beam evaporation ${ }^{[6-8]}$. The mirrors are installed in two main locations on the NIF. The first location is the multi-pass cavity where two mirrors comprise the ends of the cavity and a third is paired 
with the polarizer in a periscope assembly (Fig. 1). The mirror located on the amplifier end of the cavity is a deformable mirror composed of a matrix of 39 precision actuators installed on the rear surface of the substrate ${ }^{[9]}$. These actuators can modify the surface topography of the mirror (i.e. coating) to correct for system optical aberrations. The second cavity-end mirror consists of the same multi-layer coating design but deposited on a static substrate. The periscope mirror is used in conjunction with the optical switch (PEPC and polarizer) to direct the beam in and out of the multi-pass cavity.

The second major location where mirrors are installed is in two large bays called the "switch yards" (Fig. 1) ${ }^{[1]}$. These mirrors are used to transform the 2-dimensional, planar geometry of the 192 output beams from the main laser into the 3dimensional spherical configuration required for target illumination. These mirrors also use $\mathrm{HfO}_{2} / \mathrm{SiO}_{2}$ multi-layer stacks but the designs vary somewhat to account for the different use angles ${ }^{[10,11]}$.

All $\mathrm{SiO}_{2}$ and KDP transmissive optics in the NIF beamlines are coated with quarter-wave anti-reflection coatings. The coatings consist of a porous layer of silica nano-particles deposited by either a dip or spin-coating process from a solcontaining alcohol/water solution ${ }^{[12-14]}$. The coatings are about $50 \%$ porous with an effective refractive index of $1.23 \pm 0.02$ and have a single-surface transmission of $>99.5 \%$ on $\mathrm{SiO}_{2}(\mathrm{n}=1.45)$ and $\mathrm{KDP}(\mathrm{n}=1.5)$.

The NIF target area houses a 10-meter diameter vacuum target chamber that contains 48 laser entry ports. Each laser port allows four laser beams (a "quad") to enter the chamber ${ }^{[1,15]}$. Mounted on each entry port is a precision optical assembly containing four separate optical cells (one for each beam). Each cell in turn holds several precision optical elements (Fig. 2). A thick fused silica window provides vacuum isolation of the target interior from the surrounding ambient atmosphere. Next, there is a dual-crystal frequency converter (comprised of KDP and deuterated-KDP) that converts the fundamental $1053 \mathrm{~nm}$ laser output to $351 \mathrm{~nm}$. The converted light enters the final focusing lens that is purposely wedged to refract any unconverted light (at 1053 and $526.5 \mathrm{~nm}$ ) away from the target. Also included in this optical assembly is a full-aperture diffraction grating (one per beam), used to diffract about $0.2 \%$ of the beam energy to a diagnostic package. The last optic in each NIF beamline is a relatively low-cost fused silica debris shield that blocks target debris from hitting the more expensive optics contained in the final optics assembly.

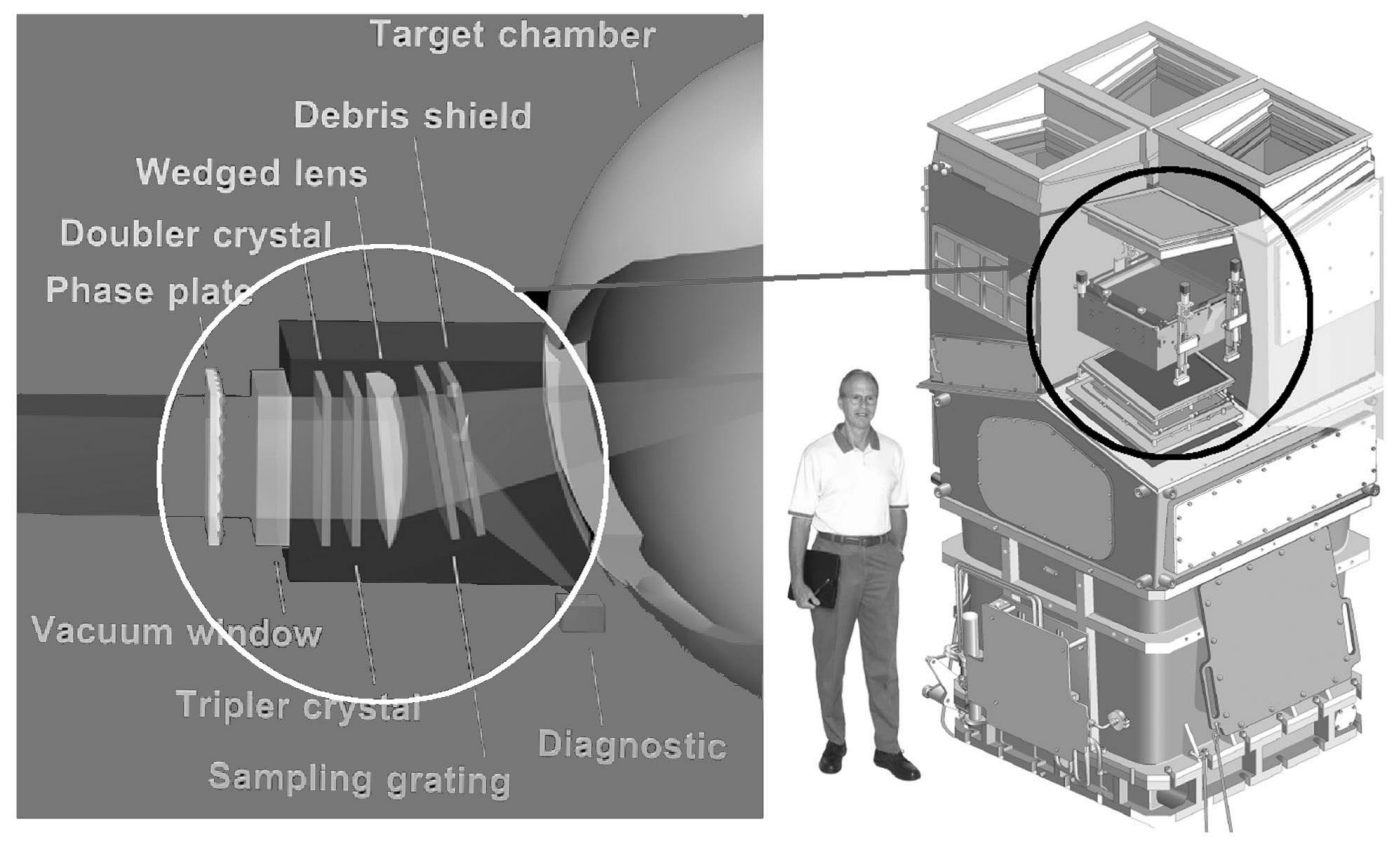

Fig. 2. Schematic drawing of the Final Optics Assembly (FOA) showing the key optical elements and their relative locations when fully assembled. Note the FOA is designed to accommodate four separate NIF beams (a "quad"). 
The target chamber optical assemblies also allow for the installation of a "phase plate" ${ }^{\text {"[16] }}$. Many of the proposed NIF target experiments require a spatially smoothed, super-gaussian far-field spot; these far field profiles can be produced using full-aperture, custom designed, fused silica phase plates installed in each of the precision optical cells. Each phase plate is imprinted with a prescribed random phase profile on one of the surfaces ${ }^{[17]}$. The phase profiles are tailored to give specific far field spot sizes, shapes (round, elliptical, etc) and super-gaussian character.

Further details of the NIF design and key components can be found in other NIF-related papers in these proceedings.

\section{NIF OPTICAL MATERIALS AND FABRICATION TECHNOLOGY}

Among the many challenges in designing and building NIF have been the multi-year research and development effort on optical materials, optics design, and optics manufacture needed to achieve the NIF performance specifications, manufacturing rate and cost goals. A full discussion of this effort is beyond the scope of this paper. Instead we present a summary of the development approach done jointly with out vendors followed by a brief description of the advances in optical materials and optical processing necessary to manufacture the NIF optics. This summary is supplemented with an extensive list of references that describe the work in detail.

\subsection{NIF vendors, advanced materials and manufacturing methods}

To develop the NIF optical materials and advanced manufacturing methods, LLNL has partnered with a number of key optical vendors across the world (Fig. 3). This approach builds on a 25-year tradition of closely working with the private sector to develop and manufacture the optics needed for the high-energy laser systems constructed at LLNL, specifically: Beamlet (1991-94), Nova (1980-85), Novette (1983), Shiva (1974-76), Argus (1973) and Janus (1971) ${ }^{[4,18-20]}$.

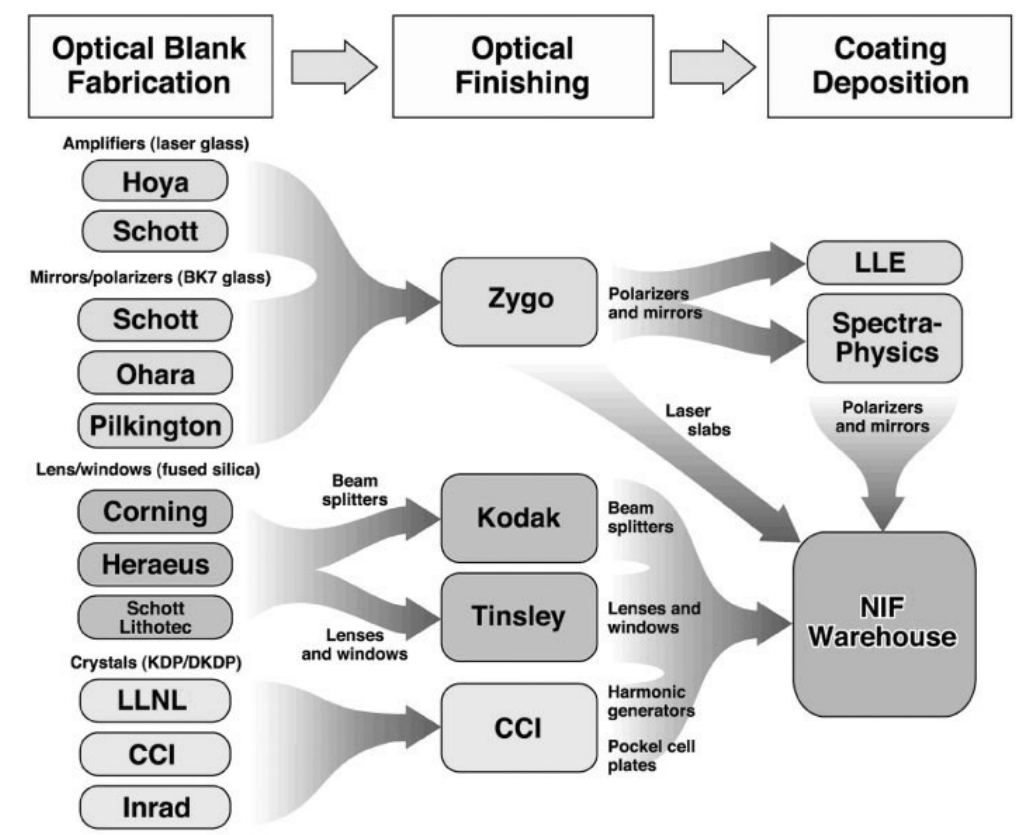

Fig. 3. The NIF optics are manufactured by the group of well-known optical vendors shown above. They supply either (1) raw glass blanks or crystal boules, (2) finished flats and/or aspheres or (3) multi-layer optical coatings for mirrors and polarizers. The work flow is indicated by the arrows on the chart. The completed optics are shipped to a warehouse near the NIF where they are stored until being cleaned, assembled and installed in the laser beam path.

In general, our approach to large optic manufacturing involves four steps (Fig. 4): (1) development, (2) design and construction of manufacturing facilities, (3) start-up and "pilot" production and (4) full production. The development stage includes not only the development of the optical materials and advanced manufacturing tools and processes but also the advanced metrology tools needed to test and verify the performance of the finished optics. During the second 
step (design and construction of optics manufacturing facilities) we funded the construction and installation of approximately $150,000 \mathrm{ft}^{2}$ of new optics manufacturing space and advanced processing equipment. These state-of-theart facilities were then commissioned by the third step (i.e. pilot operations), during which time a small percentage (5$10 \%$ ) of the required optics were manufactured to shake-down and troubleshoot the process and verify that performance and cost goals could be met. The NIF large optics are now at the final step: full production. We are currently manufacturing optics at a combined rate of nearly 100 per month; this meets the schedule of 2007 for completing production of the optics required for the NIF 192 beam lines.

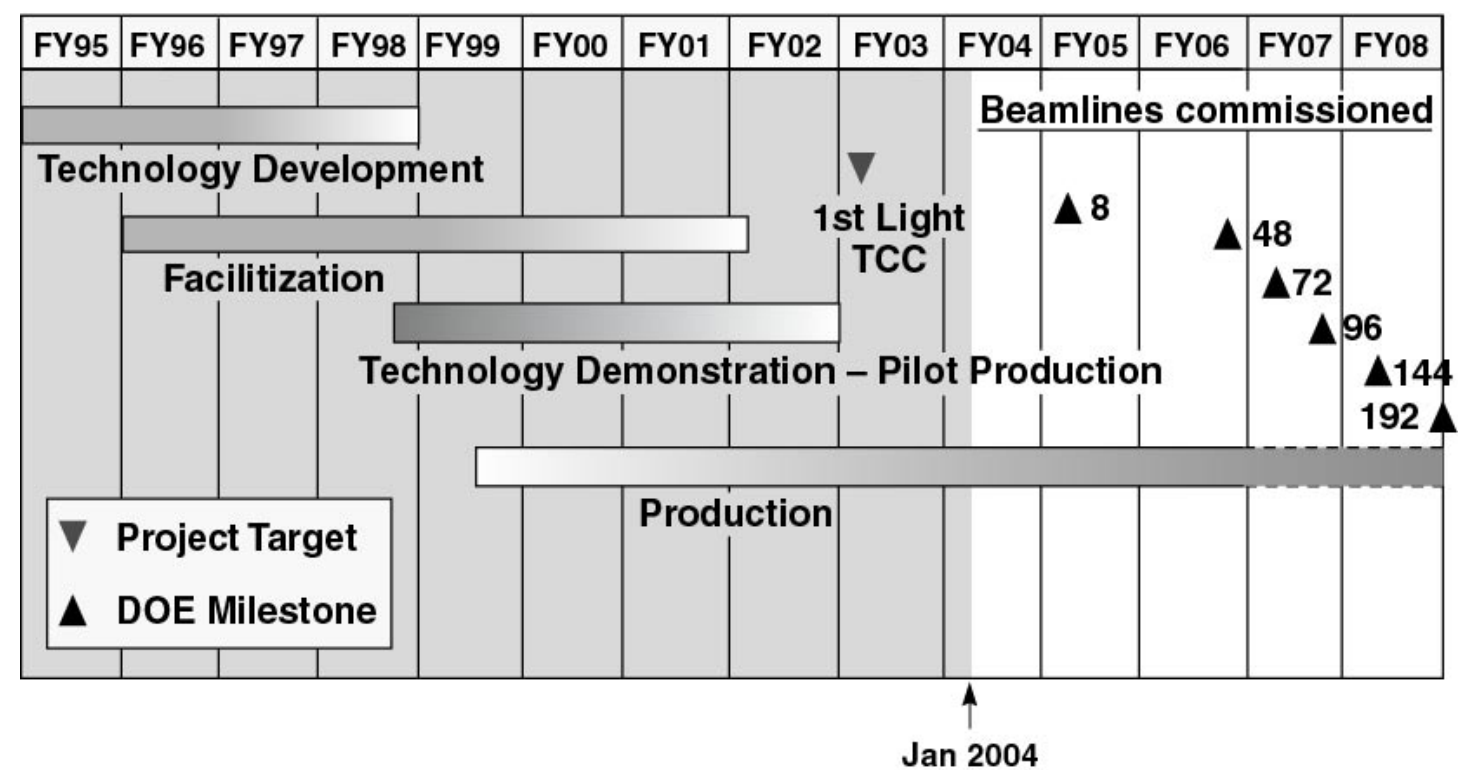

Fig. 4. A four-part program is being followed to produce the NIF optics: (1) development, (2) construction of the facility and processhardware, (3) pilot operations and (4) full production. At the time of this publication (January 2004), the NIF optics effort is in its $10^{\text {th }}$ year and on schedule for completion in 2008. The first four laser beamlines ("first light") were fired to target chamber center in December 2002. The chart time scale is in units of the U.S. government fiscal year (Oct. to Oct.)

A number of the critical optical technologies required for the NIF were demonstrated in 1994-95 on "Beamlet", a singlebeam prototype of a NIF laser beam ${ }^{[4]}$. However, to meet the demands of NIF for compact design, improved performance plus reliable, rapid and low-cost manufacturing required significant additional development. Therefore, beginning in 1995 we initiated a multi-year effort to further improve NIF optical materials and develop new manufacturing technologies. As a result of this effort we can now manufacture the NIF precision large optics with better performance, $3-5 \times$ lower unit-price and at roughly a 5-20× greater throughput than was achieved for Nova plus Beamlet combined. Some of these improvements include:

- New laser glass compositions ${ }^{[21]}$, better glass property characterization ${ }^{[22-29]}$, advanced glass processing technology ${ }^{[30-34]}$ and continuous optical glass melting methods ${ }^{[35]}$

- Novel glass asphere and flat fabrication technologies using state-of-the-art deterministic figuring methods ${ }^{[5,36,37]}$

- $10 \times$ faster KDP/DKDP crystal growth methods ${ }^{[38-40]}$ with a better scientific understanding of the growth process $^{[41-46]}$ and novel high-capacity precision crystal finishing machines.

- Laser damage resistant dielectric mirrors and polarizers manufactured to stringent multi-wavelength reflection and transmission specifications ${ }^{[7,10,11,47-55]}$

- Environmentally stable, laser damage-resistant, sol-gel anti-reflection coatings ${ }^{[14,56-59]}$

- Novel diffractive grating and continuous phase plate design and fabrication methods ${ }^{[16,17]}$.

The quality of the optics produced for NIF has surpassed our expectations and are significantly better than the specification giving added design margin to the laser system (Fig. 5). 


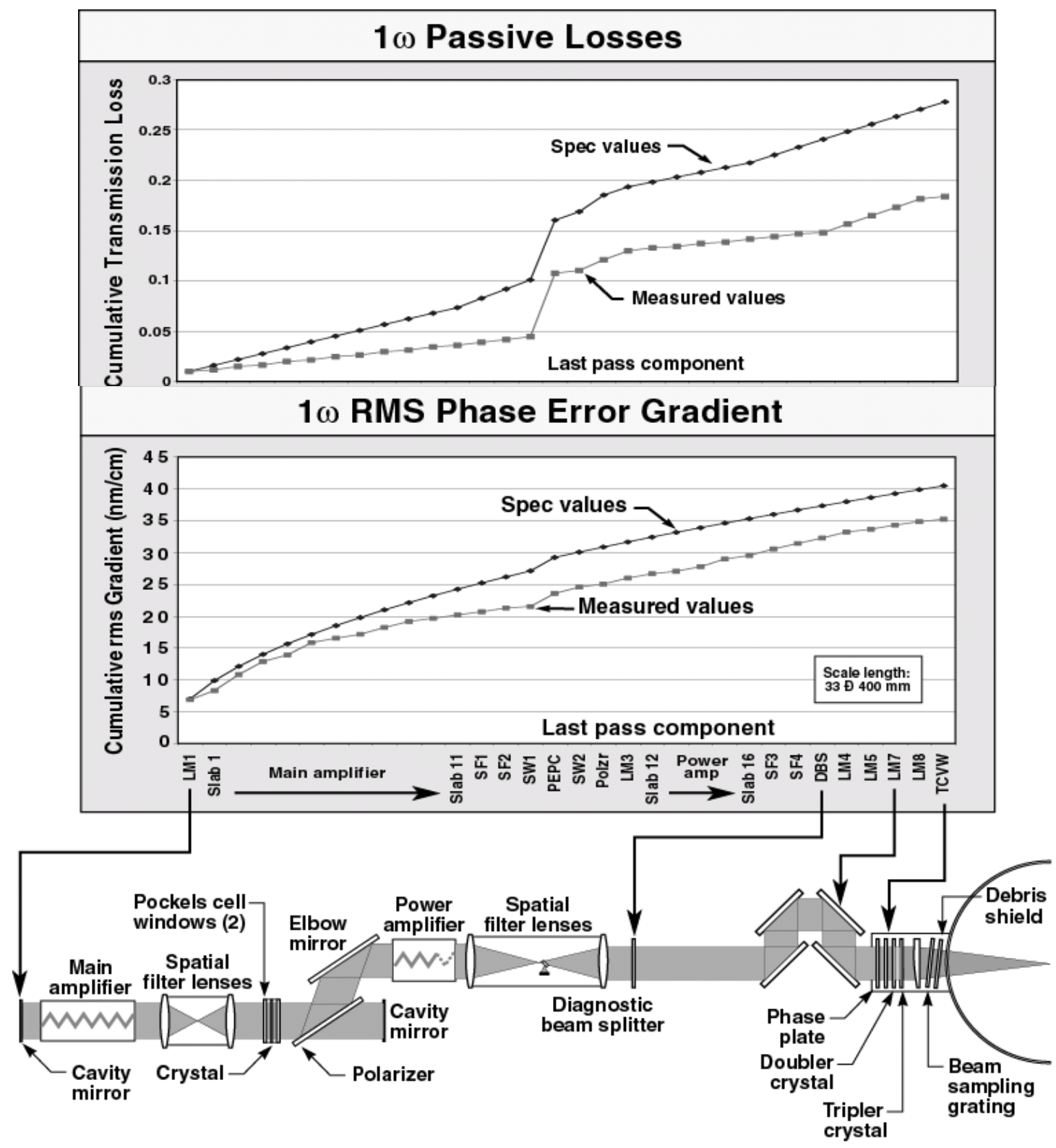

Fig. 5. In general, the majority of NIF optics are significantly better than specification. This is illustrated here for two critical specifications: (a) the rms gradient specification that impacts the far-field spot on target, and (b) the passive optical losses that impact the overall energy delivered. The results show the cumulative contribution of these effects on the final pass through the laser chain. Note that both the cumulative measured gradient and optical loss are significantly better (lower) than the specification.

\subsection{Optical specifications and metrology tools}

To produce the NIF optics required the development, construction and installation of a number of custom optical metrology tools. For example, ten, 24-inch phase-measuring interferometers were installed at the various manufacturing facilities for measuring the wavefront quality of both the optical blanks as well as the final finished optic. At the time we started the optics manufacturing development effort, commercial phase-measuring interferometers of this size were not available. Consequently LLNL contracted with Wyko and Zygo to produce the needed instruments. These interferometers are used to test the full-aperture transmitted or reflected wave-front quality of every manufactured optic. 
In addition, four custom high-power laser-scanning systems were developed and installed for full aperture testing of laser glass and dielectric coatings for potential damage causing defects ${ }^{[55]}$. Also precision, scanning photometers have been installed at the NIF coating vendors and at LLNL to QA the full-aperture transmission and reflection performance of the coated optics. Finally, precision crystal alignment tools have been developed and fielded to verify that the frequency conversion crystals are fabricated to the prescribed phase matching angles.

The wavefront quality of the optics used on our prior large laser systems (Beamlet, Nova, etc.) was specified and measured over two widely separated spatial frequency regions. One region covered the full aperture and specified the wavefront in terms of the standard aberration parameters: sphere, coma and astigmatism, etc. (i.e., the low order Zernike terms). The other region was at a high spatial frequency and specified the surface micro-roughness.

As mentioned above, by the time the NIF project started (1995) a new class of phase measuring interferometers with mega-pixel cameras was becoming available. These tools allow one to measure phase aberration across a continuum of spatial scale lengths (spatial frequencies) from $\mu \mathrm{m}$ to $\mathrm{m}\left(\mu \mathrm{m}^{-1}\right.$ to $\left.\mathrm{m}^{-1}\right)$. Of course, no one tool could transverse the entire region but the use of a large-aperture phase interferometer capable of covering the low to mid frequency region in combination with a small-aperture surface-measuring phase interferometer for measuring the high frequency regions provides NIF this full capability.

Because of this newly available metrology resource, the wavefront quality of the NIF optics is specified over a continuous range of spatial frequencies from $1 \times 10^{2}$ to $2.5 \times 10^{-3} \mathrm{~mm}^{-160-62]}$. This range of frequencies is divided into the four separate bands as shown in Fig. 6 and summarized in Table 2.

Table 2. The finished NIF glass and crystal optics are specified by the parameters listed below for four separate bans covering a spatial frequency from $2.5 \times 10^{-3}$ to $100 \mathrm{~mm}^{-1}$. Rq is the rms "waviness" or roughness and $A$ is the amplitude parameter of the PSD not-to-exceed function used to specify bands 2 and 3. See text and Fig 6 for details; all values are for $\lambda=633 \mathrm{~nm}$.

\begin{tabular}{|c|c|c|c|c|c|c|c|}
\hline Measured band & \multicolumn{2}{|c|}{ Band 1} & \multicolumn{2}{|c|}{ Band 2} & \multicolumn{2}{|c|}{ Band 3} & Band 4 \\
\hline $\begin{array}{l}\text { Spatial scale length } \\
(\mathrm{mm})\end{array}$ & \multicolumn{2}{|c|}{400 to 33} & \multicolumn{2}{|c|}{33 to 2.5} & \multicolumn{2}{|c|}{2.5 to 0.12} & 0.12 to 0.01 \\
\hline $\begin{array}{l}\text { Spatial frequency } \\
\left(\mathrm{mm}^{-1}\right)\end{array}$ & \multicolumn{2}{|c|}{$2.5 \times 10^{-3}$ to $3.0 \times 10^{-2}$} & \multicolumn{2}{|c|}{$3.0 \times 10^{-2}$ to 0.4} & \multicolumn{2}{|c|}{0.4 to 8.3} & 8.3 to 100 \\
\hline Parameter & $\begin{array}{l}\text { P-to-V } \\
\text { (waves) }\end{array}$ & $\begin{array}{c}\text { rms } \\
\text { gradient } \\
(\mathrm{nm} / \mathrm{cm})\end{array}$ & $\begin{array}{c}\mathrm{Rq}(\mathrm{rms}) \\
(\mathrm{nm})\end{array}$ & $\begin{array}{c}\mathrm{A} \\
\left(\mathrm{nm}^{2} \bullet \mathrm{mm}\right)\end{array}$ & $\begin{array}{l}\mathrm{Rq}(\mathrm{rms}) \\
(\mathrm{nm})\end{array}$ & $\begin{array}{c}\mathrm{A} \\
\left(\mathrm{nm}^{2} \bullet \mathrm{mm}\right)\end{array}$ & $\begin{array}{l}\mathrm{Rq}(\mathrm{rms}) \\
\quad(\mathrm{nm})\end{array}$ \\
\hline \multicolumn{8}{|l|}{ Optic type: } \\
\hline Glass & 0.33 & 7 & 1.8 & 1.0 & 1.6 & 1.0 & 0.4 \\
\hline Crystal & - & 11 & 5 & 15 & $\begin{array}{c}2.6 \mathrm{pk} \\
(1.5 \mathrm{avg} .)\end{array}$ & 15 & $\begin{array}{c}2.5 \mathrm{pk} \\
(1.5 \mathrm{avg} .)\end{array}$ \\
\hline
\end{tabular}

The wavefront quality over the first band, $2.5 \times 10^{-3}$ to $3.0 \times 10^{-2} \mathrm{~mm}^{-1}$, is specified simply in terms of a maximum peak-tovalley error and a maximum rms phase gradient. For all the glass optics, the peak-to-valley specification is $<\lambda / 3$ and the gradient $<\lambda / 90 / \mathrm{cm}$ (measured at $\lambda=633 \mathrm{~nm}$ ). This region controls the spot size at the target plane. NIF's deformable mirror, located at the end of the multipass cavity, (see Fig. 1) can fully correct for these wavefront aberrations.

In the spatial frequency region from $3.0 \times 10^{-2}$ to $8.3 \mathrm{~mm}^{-1}$ we define a maximum "waviness" in terms of a power spectral density (PSD). The PSD simply represents the square of the phase noise amplitude $\left(\mathrm{nm}^{2}\right)$ over a certain spatial frequency $\left(\mathrm{mm}^{-1}\right.$ ) and thus has the unusual set of units $\mathrm{nm}^{2} / \mathrm{mm}^{-1}$ or $\mathrm{nm}^{2} \mathrm{~mm}$ (see Fig. 6). Currently no single phasemeasuring interferometer is capable of spanning this entire PSD spatial frequency region. Therefore we break this region into two parts: "waviness 1" (PSD1) and "waviness 2" (PSD2) as shown in Fig. 6. 
The waviness (PSD) is defined in two ways. First, the power associated with any given Fourier component (spatial frequency) cannot exceed a limit defined by $\mathrm{A}^{\cdot}\left(\mathrm{f}^{-1.55}\right)$ where $\mathrm{A}\left(\mathrm{nm}^{2} \mathrm{~mm}\right)$ is an empirically derived constant and $\mathrm{f}\left(\mathrm{mm}^{-1}\right)$ is the spatial frequency; this limit is labeled as the "not-to-exceed line" shown in Fig. 6 for the glass optics. We specify two different values for the constant A: one for finished glass optics $\left(1.0 \mathrm{~nm}^{2} \mathrm{~mm}\right)$ and the other for finished crystal plates $\left(15.0 \mathrm{~nm}^{2} \mathrm{~mm}\right)$. We also specify that the integral of the measured PSD over the associated spatial frequency band cannot exceed a given value. This integral is equivalent to the rms waviness and represents the magnitude of the phase noise over that region. Note that the real optic produces a 2-dimensional PSD phase noise profile. In order to compare the measurements with the 1-dimensional not-to-exceed line we perform a 1D "collapse" of the 2D data. This and other aspects of the data reduction procedure and associated algorithms are described in detail by Williams ${ }^{[62]}$.

(a)

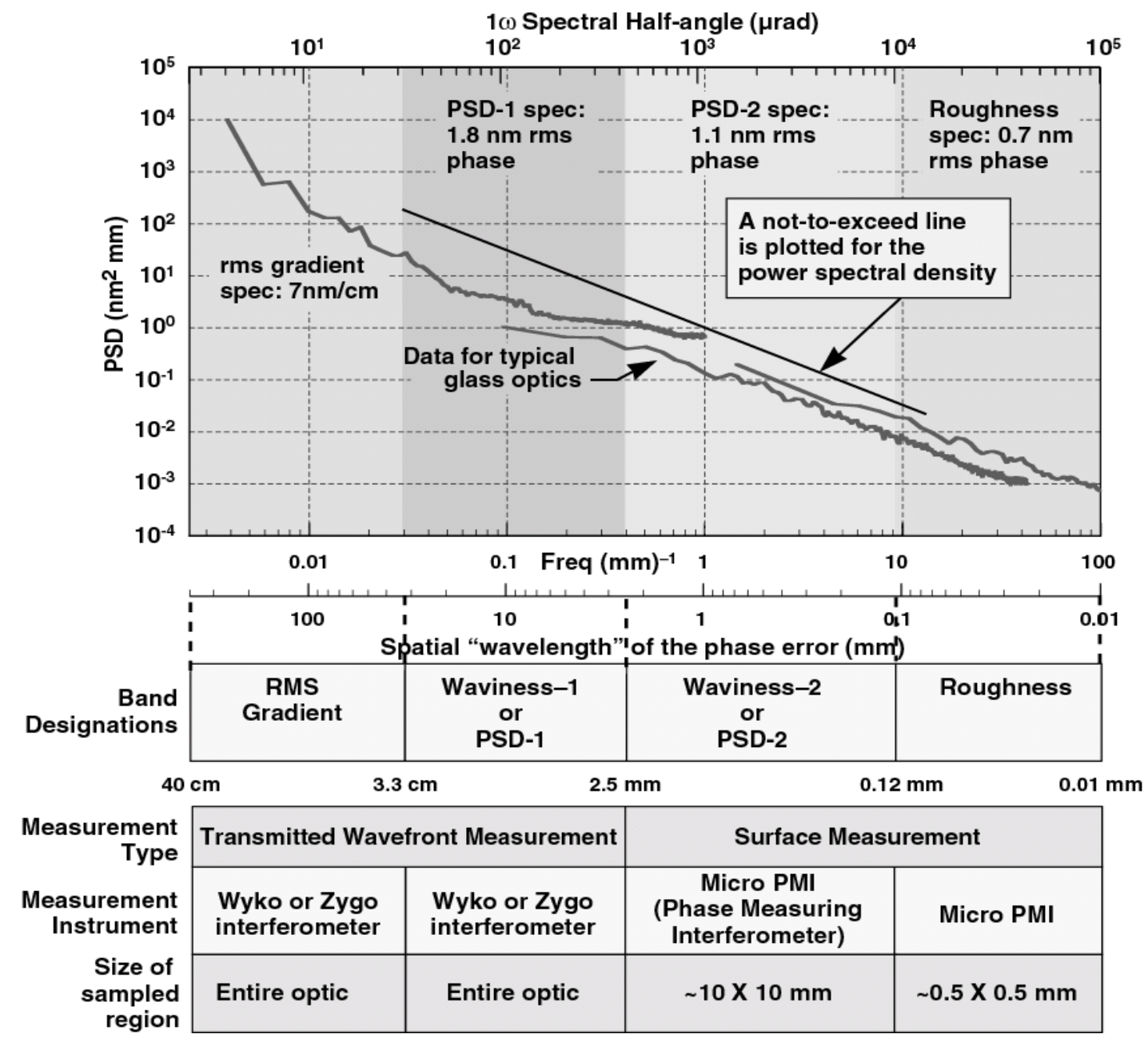

Fig. 6. (a) The wavefront quality of the NIF optics is specified across four contiguous spatial frequency regions from $0.0025 \mathrm{~mm}^{-1}$ to $100 \mathrm{~mm}^{-1}$. Shown here are the specifications for just the finished glass optics. The two intermediate regions (PSD1 and 2) are specified in terms of a maximum rms phase error as well as a maximum power spectral density at any given spatial frequency represented by the "not-to-exceed" line in the figure. (b) The measurements over the spatial frequency bands are carried out using the instruments listed in the figure and over a sampling region that includes the entire optic (for rms gradient and PSD-1) or several smaller, sub-apertures (for PSD-2 and roughness). The rms phase error values given here are for the transmitted wavefront equivalent; to convert to surface values multiply by $\sqrt{2}$. All measurements (and specifications) are at $633 \mathrm{~nm}$.

Physically, the rms and not-to-exceed specifications ensure (1) that the total scattered light due to the waviness in this frequency band does not exceed a given value (the rms phase noise specification does this) and (2) that the quantity of light scattered due to any one spatial frequency is below a fixed value (i.e. there is no "grating effect"). This latter point 
roughly defines the limiting amplitude at a given spatial frequency beyond which subsequent nonlinear growth in the phase noise becomes unacceptable at high operating intensities.

The fourth spatial frequency band is from 8.3 to $100 \mathrm{~mm}^{-1}$ and represents the micro-roughness region. This measurement is carried out over nine sub-apertures $\left(0.5 \times 0.5 \mathrm{~mm}^{2}\right)$ and specified as an average rms value for the glass optics (in most cases $<0.4 \mathrm{~nm})$. For the crystal optics we specify both an average $(<1.5 \mathrm{~nm})$ and a peak $(<2.5 \mathrm{~nm})$ roughness for the nine sub-apertures.

The crystals have some additional specifications that account for features in the material that naturally occur as a result of the growth process (Table 3). Specifically, the crystals often show distinct boundaries between the surfaces on which the crystal grows, the so-called "prism" $\{1,0,0\}$ and pyramid" $\{1,1,1\}$ faces ${ }^{[38,39]}$. Variations can also occur along a given growth direction due to changes in growth parameters (cation impurity levels, growth rate, rotation speed, etc.). Evidence for these boundaries is a measurable "phase jump" when viewed in an interferometer. The magnitude of the allowed phase jump depends on the distance over which it occurs as summarized in Table 3. Clearly a sharp phase change implies a high gradient which is much more problematic than a slowly varying change (i.e. lower gradient). Based on our experience to date, the NIF crystals easily pass the phase-jump specification.

Another specification that applies just to the conversion crystals is a maximum rms birefringence $\left(\mathrm{n}_{\mathrm{e}}-\mathrm{n}_{\mathrm{o}}\right)$ when measured interferometrically at two orthogonal polarizations (i.e. OPI: orthogonal polarization interferometry). This specification accounts for the high angular sensitivity ( $\mu$ rad range) of the frequency conversion process ${ }^{[15]}$ and the impact of small deviations from the phase matching direction caused by minor internal variations in the crystal refractive indices.

Table 3. Specified limits to measured localized phase discontinuities $(\Delta \phi)$ and rms spatial birefringence variations $\left(\Delta \mathrm{n}=\mathrm{n}_{\mathrm{e}}-\mathrm{n}_{\mathbf{0}}\right)$ for the NIF plasma-electrode Pockels cell (PEPC), frequency doubling (SHG) and tripling (THG) crystals.

\begin{tabular}{|l|c|c|c|}
\hline \multicolumn{1}{|c|}{ Parameter } & PEPC & SHG & THG \\
\hline$\Delta \phi($ waves at $633 \mathrm{~nm})$ & & & \\
over distance $\mathrm{L}:$ & & & \\
$0<\mathrm{L}<3 \mathrm{~mm}$ & $0.025+0.015 \mathrm{~L}^{2}$ & $0.029+0.016 \mathrm{~L}+0.022 \mathrm{~L}^{2}$ & $0.029+0.016 \mathrm{~L}+0.022 \mathrm{~L}^{2}$ \\
$3<\mathrm{L}<33 \mathrm{~mm}$ & 0.16 & 0.28 & 0.28 \\
\hline $\begin{array}{l}\Delta \mathrm{n}(\mathrm{rms}) \times 10^{-6} \\
\begin{array}{l}\mathrm{D}=\text { fractional } \\
\text { deuteration) }\end{array}\end{array}$ & - & 1.0 & $3.0-0.5 \mathrm{D}$ \\
\hline
\end{tabular}

There are several subtle aspects of the NIF optics wavefront specification that should be mentioned. First, at high intensities the phase noise can grow non-linearly for certain spatial frequencies. Therefore, the effect on the laser performance can be much worse if the rms noise is compressed into one narrow band rather than being spread across the entire spectrum. Consequently, we specify an rms noise limit (i.e. the integral of the measured PSD curve) that is less than the integral under the not-to-exceed line.

Second, the specifications have been formulated to account for the fact that some optics are more difficult to manufacture than others. Therefore the values of the not-to-exceed parameters and the rms phase noise over certain bands are less stringent for these more difficult optics. The crystals are one example of this; the not-to-exceed limit and rms gradient are somewhat higher to account for the higher gradients in crystals as discussed above as well as the greater level of waviness that is produced by the current state-of-the-art machine tools used to finish the crystals. Another example is the spatial filter lenses; because of the long back focal lengths of these lenses, we specify the optic wavefront over two regions, the central $85 \%$ of the aperture and the outer remaining $15 \%$. The central region is easier to manufacture and is specified to the limits as shown in Fig 6. The outer area has a less stringent PSD1 rms requirement $(2.7$ vs. $1.8 \mathrm{~nm})$ and the not-to-exceed limit is higher $(\mathrm{A}=1.5 \mathrm{vs} .1 .0)$. The ability to slightly relax the specifications of the more difficult optics gives considerable cost savings without sacrificing performance. This is simply because the quality, on average, of all the NIF optics is better than our specifications (see Fig. 5). 


\section{IMPROVING OPTICS LIFETIME}

Although there are many technological and scientific challenges to developing optics for high-power-lasers, perhaps the most critical challenge has been the reduction and, where possible, elimination of laser-induced damage. This is a continuing challenge because as new laser-damage-resistant optical materials and fabrication technologies are developed, laser designers increase the system operating energies and powers to the limits of these new materials ${ }^{[63-66]}$. The reason is both economically and scientifically driven; the higher the damage resistance of the optics, the longer the lifetime of the optic as fluence levels become more stressing, and the greater the laser output energy that can be achieved for a given cost. The amount of work devoted to improving the damage resistance of laser materials is truly enormous; at LLNL alone we have had a continuous research effort in this area for over 30 years. In addition, an annual SPIE conference is devoted just to this subject; the reader is referred to these proceedings for a more exhaustive survey of the field ${ }^{[67]}$.

The NIF laser damage research effort is divided into three broad material categories: bulk optical materials, polished optical surfaces, and optical coatings (reflection, antireflection and polarizing). We study the damage performance of the materials at their intended use wavelengths $(1053,526$, and/or $351 \mathrm{~nm})$ and pulse lengths ( 1-20 ns).

The bulk optical materials receiving the most attention are KDP, DKDP, $\mathrm{SiO}_{2}$ (fused silica) and phosphate laser glasses. Much of the glass bulk material research has focused on damage induced by inclusions as well as new processing methods developed by the vendors to eliminate inclusions (see for example ${ }^{[63]}$ and references cited therein). As a result, $\mathrm{SiO}_{2}$ and phosphate laser glasses can now be made essentially "inclusion-free". There has also been significant research to understand the bulk damage of KDP and $\mathrm{DKDP}^{[64,68-76]}$ and it has been shown that the damage threshold can be significantly improved by laser or thermal conditioning ${ }^{[64,68,69,75,76]}$. Laser conditioning refers to the pre-irradiation of the optic with incremental laser fluences that ultimately approach the NIF operating levels. This pre-irradiation process is carried out by raster scanning the optic using the output from a commercial pulsed laser system operating at 1064 (NdYAG) or $351 \mathrm{~nm}$ (excimer). Laser conditioning increases the damage resistance of KDP Pockels cell crystals by $3 \times$, of KDP doublers by $2 \times$ and DKDP triplers by $1.5 \times$. In contrast thermal conditioning is less effective and only applicable to KDP; thermal treatment generally increases the damage threshold by about $50 \%$.

Laser interaction with polished optical surfaces is also a subject of great importance to the NIF. The damage resistance of polished $\mathrm{SiO}_{2}$ and phosphate glass surfaces at $1053 \mathrm{~nm}$ is higher than the NIF use conditions ${ }^{[2,65,66]}$ and therefore is not a problem as long as the optics are installed and used in a clean environment. The damage resistance of $\mathrm{SiO}_{2}$ optical surfaces at $351 \mathrm{~nm}$ is naturally lower because the laser wavelength is closer to the band gap of the material. Thus any defect states with energies in the band gap or absorbing contaminants (for example from the polishing process) can lead to damage. Consequently, we have focused on improved polishing processes and polishing materials with particular attention to eliminating residual subsurface damage. This includes the use of polishing slurries comprised of large bandgap abrasives. Specifically, we have looked at the use of $\mathrm{ZrO}_{2}$ and $\mathrm{SiO}_{2}$ containing slurries versus the commonly used but near-UV absorbing $\mathrm{CeO}_{\mathrm{x}}$ based slurries.

We have also found that post-processing treatment of the polished $\mathrm{SiO}_{2}$ surfaces improves the $351 \mathrm{~nm}$ damage resistance. Specifically, etching the polished surface with a buffered HF acid solution removes both embedded polishing contaminants and subsurface damage ${ }^{[79]}$. Laser conditioning of the polished surfaces is another post-polishing step that has been shown to improve the damage resistance of $\mathrm{SiO}_{2}$ optics ${ }^{[79]}$. Our presumption is that the conditioning process gently ejects or ablates any absorbing contaminants on or near the surface.

In the case of the $\mathrm{SiO}_{2}$ optics, we have also developed a novel method for mitigating damage sites that may be initiated during the laser conditioning process. This mitigation process uses the output from a $\mathrm{CO}_{2}$ laser to locally heat and melt the surface region around the damage site thus making it resistant to growth upon further irradiation at $351 \mathrm{~nm}^{[64,80-82]}$ (see Fig.7). Untreated initiation damage sites have been shown to grow exponentially with continued irradiation ${ }^{[83-84]}$ thus this type of mitigation process is important for extending the operating life of the optic.

We have also found that the use of magnetorheological (MRF) polishing of $\mathrm{SiO}_{2}$ optics followed by etching and laser conditioning gives significantly improved damage performance ${ }^{[78]}$. It has been proposed that the lower normal loads 
associated with MRF vs. conventional polishing reduces surface fracture (defect) generation. Material removal by MRF occurs largely by shear ${ }^{[36,85,86]}$.

The NIF mirrors and polarizers use $\mathrm{HfO}_{2} / \mathrm{SiO}_{2}$ coatings for the main reason that they can be laser conditioned to increase the damage resistance. The laser conditioning has been shown to increase the damage threshold by 2 to $3 \times{ }^{[6-8,53,87-91]}$. In fact, laser conditioning is now an integral part of the optical production process and is simply treated as an added processing step; laser conditioning systems have been supplied to the coating vendors solely for this purpose. Conditioning of $\mathrm{HfO}_{2} / \mathrm{SiO}_{2}$ coatings was first reported in the late ' 80 ' $\mathrm{s}^{[87]}$. Subsequent research has shown that the conditioning process "works" by gently ejecting nodular defects within the coating ${ }^{[6,8,92-94]}$. The interface of the nodules with the main coating tends to be porous and mechanically weak. Moreover, it is likely that optically absorbing defects populate the interface. Research is on-going to understand the physics and chemistry of $\mathrm{HfO}_{2} / \mathrm{SiO}_{2}$ coating damage, damage growth and conditioning ${ }^{[48,50,52,95-97]}$.

Laser damage resistant antireflection coatings are comprised of single quarter-wave layers of silica sol-gel applied by a dip or spin process. This coating was developed during the construction of the Nova laser in the mid-1980's ${ }^{[59]}$. Since that time it has become the AR coating of choice for high-fluence applications. The NIF uses a modified version of this original coating that has much improved environmental durability with equivalent or somewhat improved laser damage resistance ${ }^{[56-58]}$.
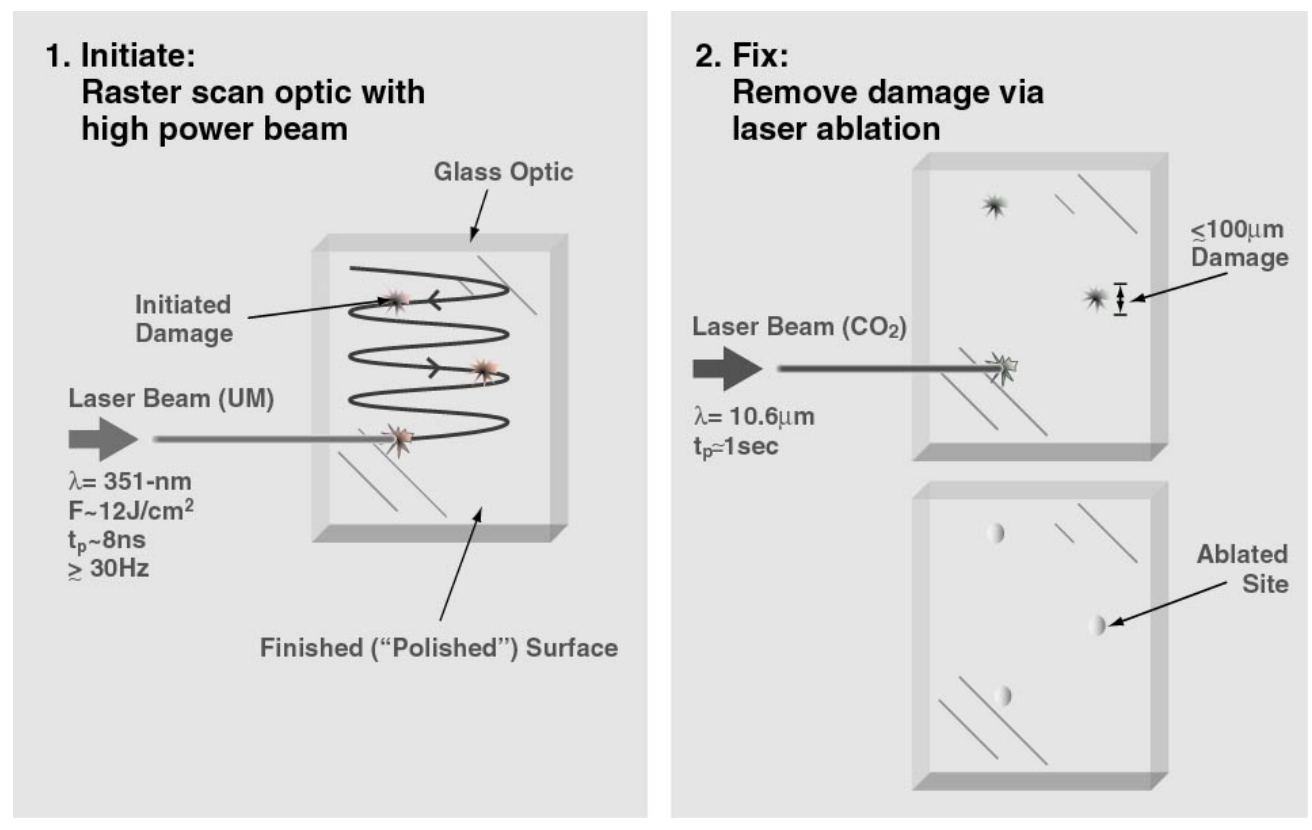

Fig. 7. Schematic diagram of process to (1) initiate and then (2) repair laser-induced damage on a polished fused silica optic ${ }^{\text {[79-81]. }}$

Our work on improving the damage resistance of the NIF optical materials has been greatly helped by a parallel theoretical and experimental effort aimed at identifying the sources and mechanisms for damage. The work by Feit et al.$^{[98-100]}$ is particularly noteworthy. Feit has developed a theoretical framework that accurately predicts surface damage initiation from the femtosecond to nanosecond range (Fig. 8). Feit has shown that there are two limiting mechanisms that control the damage process, one at short pulse lengths and the other at long pulse lengths (see Fig. 8). In the short pulse region, multiphoton ionization dominates whereas at long pulses linear optical absorption by contaminating materials is the main damage mechanism as indicated ${ }^{[99]}$ by the pulselength dependence seen for long pulses in Fig. 8 . This distinction between the two processes is critical for the work on developing more damage resistant optical materials and materials processes for NIF. Based on Feit's work and given the fact the NIF operates in the nanosecond regime, then it is clear that contamination and absorbing defects inside or on the material dominates the damage process. Therefore, our attention is concentrated toward making process improvements that eliminate all possible sources of absorbing contaminants whether they are from manufacture, improper cleaning, assembly or use on the system. 
Key to understanding damage mechanisms and quantifying damage performance is the availability of state-of-the-art damage test facilities. To support the NIF damage research we have built and are operating a suite of damage test systems capable of delivering NIF-like fluences at 1053, 526 and $351 \mathrm{~nm}{ }^{[104,105]}$. These systems have the capability of irradiating the optic with spot sizes from $\mathrm{mm}$ to several $\mathrm{cm}$. In addition, some of the systems are capable of raster scanning the entire optic. To detect damage, we have also built and fielded a set of highly sensitive inspection tools ${ }^{[106-}$

${ }^{112]}$. With these tools we can detect damage and defects down to the micron scale. We have also developed new testing methods that no longer rely on the earlier concept of a "damage threshold" but instead treats damage as a probabilistic process $^{[113,114]}$. The use of a probabilistic approach is essential when attempting to quantify the damage resistance of thousands of square meters of finished or coated surfaces and hundreds of metric tons of bulk optical materials assembled on the NIF.

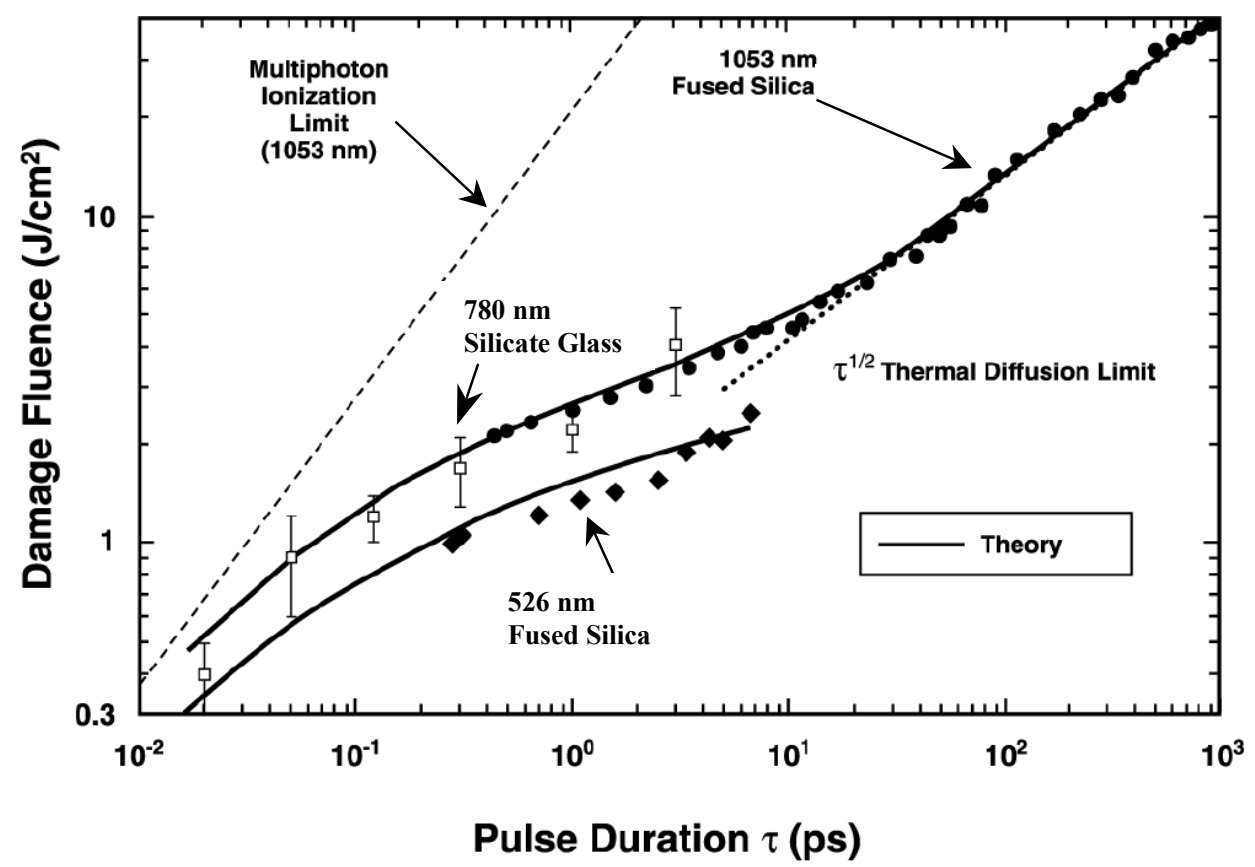

Figure 8:Comparison of predicted versus measured fluence for laser-induced damage to polished $\mathrm{SiO}_{2}$ surfaces at $1053(\bullet)$ and 526 $\mathrm{nm}(\bullet)^{[98]}$ and to a barium alumino-borosilicate glass surface at $780 \mathrm{~nm}(\square)^{[102]}$. The theory $(-)$ is from Stuart et al ${ }^{[98]}$; note the two limiting mechanism: multi-photon ionization (---) and thermal diffusion (...)

\section{ACKNOWLEDGMENTS}

The authors gratefully acknowledge the many people, institutions, and industrial partners that are diligently working to build the National Ignition Facility. This work was performed under the auspices of the U.S. Department of Energy by the University of California, Lawrence Livermore National Laboratory under contract W-7405-Eng-48. 


\section{REFERENCES}

[1] E. I. Moses, J. H. Campbell, C. J. Stolz, and C. R. Wuest, "The National Ignition Facility: the world's largest optics and laser system," in Optical Engineering at the Lawrence Livermore National Laboratory, T. T. Saito and M. A. Lane, eds., Proc. SPIE 5001, 1-15, (2003).

[2] M. A. Rhodes, B. Woods, J. J. DeYoreo, D. Roberts, and L. J. Atherton, "Performance of large-aperture optical switches for high-energy ICF lasers", Appl. Opt. 34, 5313-5330 (1995).

[3] J. Goldhar and M. A. Henesian, "Large-aperture electrooptical switches with plasma electrodes", IEEE J. Quantum Electron. QE22, 1137-1147 (1986).

[4] B. M. Van Wonterghem, J. R. Murray, J. H. Campbell, D. R. Speck, C. E. Barker, I. C. Smith, D. F. Browning and W. C. Behrendt, "Performance of a prototype for a large-aperture multi-pass Nd:glass laser for inertial confinement fusion", Appl. Opt., $\underline{36}$ (1997) p. 4932.

[5] T. G. Parham, C. J. Stolz, T. Baisden, M. Kozlowski, C. Kiikka and D. M. Aikens, "Developing optics finishing technologies for the National Ignition Facility", ICF Quarterly Report, 9 (1999), p. 177-191; LLNL Report UCRL-LR-105821-99-20.

[6] M. R. Kozlowski "Damage-resistant laser coatings," in Thin Films for Optical Systems, Marcel Dekker, Flory FR (ed), New York, pp 521-549 (1995).

[7] C. J. Stolz, C. L. Weinzapfel, A. L. Rigatti, J. B. Oliver, J. Taniguchi, R. P. Bevis, and J. S. Rajasansi, "Fabrication of meter-scale laser resistant mirrors for the National Ignition Facility, a fusion laser," in Advances in Mirror Technology for X-ray, EUVL, Lasers and Other Applications, A. M. Khounsary, U. Dinger, and K. Ota, eds., Proc. SPIE 5193, 50-58 (2003).

[8] C. J. Stolz and F. Y. Génin, "Laser resistant coatings", in Optical Interference Coatings in Springer Series in Optical Sciences, Eds. N. Kaiser and H. Pulker, Springer-Verlag, Berlin Heidelberg 2003.

[9] R. A. Zacharias, E. S. Bliss, S. Winters, R. A. Sacks, M. Feldman, A. Grey, J. A. Koch, C. J. Stolz, J. S. Toeppen, L. Van Atta, and B. W. Woods, "Wavefront control of high-power laser beams in the National Ignition Facility (NIF)," in Advanced High-Power Lasers, Osinski, Marek, Powell, Howard T., and Toyoda, Koichi, eds., Proc. SPIE 3889, 332-343 (2000).

[10] J. B. Oliver, J. Howe, A. Rigatti, D. J. Smith and C. J. Stolz, "High precision coating technology for large aperture NIF optics," in Optical Interference Coatings, OSA Technical Digest (Optical Society of America, Washington, DC), pp. ThD2-1 - ThD2-3, (2001).

[11] C. J. Stolz, C. L. Weinzapfel, G. T. Rogowski, D. J. Smith, A. Rigatti, J. Taniguchi, M. Von Gunten, R. P. Bevis, M. Smith and V. Ivan, "Status of optical coatings for the National Ignition Facility," in Optical Interference Coatings, OSA Technical Digest (Optical Society of America, Washington DC), pp. ThD3-1 - ThD3-3, (2001).

[12] I. M. Thomas, Appl. Opt. 25 (1986) 1481.

[13] I. M. Thomas, SPIE 2114 (1993) 232.

[14] T. I. Suratwala, M. L. Hanna, E.L. Miller, P.K. Whitman, I.M. Thomas, P.R. Ehrmann, R.S. Maxwell, A.K. Burnham, "Surface Chemistry and Trimethylsilyl Functionalization of Stöber Silica Sols in Solution", $J$. Non-Cryst. Sol. 316, 349-363 (2003).

[15] P. Wegner, J. Auerbach, T. Biesiada, S. Dixit, J. Lawson, J. Menapace, T. Parham, D. Swift, P. Whitman and W. Williams, "NIF final optics system: Frequency conversion and beam conditioning", these proceedings.

[16] S. N. Dixit, M. D. Feit, M.D. Perry and H. T. Powell, "Designing fully continuous phase screens for tailoring focal-plane irradiance profiles" Optics Letters, 21 (1996) pp. 1715-1717.

[17] J. A. Menapace, S.N. Dixit, F. Y. Genin and W. F. Brocious (Magnetorheological finishing for imprinting continuous phase plate structures onto optical surfaces, SPIE Symposium on Optical Materials for High Power Lasers (2003) in press.

[18] J. T. Hunt and D. R. Speck, "Present and future performance of the Nova laser system", Opt. Eng., 28 (1989) p. 461.

[19] W. W. Simmons and R. O. Godwin, "Nova laser fusion facility—design, engineering and assembly overview," Nucl.Technol. Fusion 4, 8-24 1983.

[20] J. Lindl, Inertial Confinement Fusion: The Quest for Ignition and Energy Gain Using Indirect Drive, SpringerVerlag (1998).

[21] J. H. Campbell and T. I. Suratwala, "Nd-doped phosphate glasses for high-energy/high-peak-power lasers", J. Non-Cryst. Solids, 263\&264 (2000) p. 318-341. 
[22] P. R. Ehrmann, K. Carlson, J. H. Campbell, C. A. Click and R. K. Brow, "Neodymium fluorescence quenching by hydroxyl groups in phosphate laser glasses", J. Non. Cryst. Solids, 2003 (in press).

[23] C. A. Click, R. K. Brow, P. R. Ehrmann and J. H. Campbell, "Characterization of $\mathrm{Pt}^{4+}$ in alumino-metaphosphate laser glasses", J. Non. Cryst. Solids, (2003) (in press).

[24] P. R. Ehrmann and J. H. Campbell, "Non-radiative energy losses and radiation trapping in Nd-doped phosphate laser glasses”, J. Am. Ceram. Soc., 85 [5] 1061-69 (2002).

[25] M. Karabulut, G. K. Marasinghe, C. A. Click, E. Metwalli, R. K. Brow, C. H. Booth, J. J. Bucher, D. K. Shuh, T. I. Suratwala, and J. H. Campbell, "XAFS Investigation of Platinum Local Environment in Phosphate Laser Glasses", J. Am. Ceram. Soc., 85 [5] 1090-99 (2002).

[26] T. I. Suratwala, R. Steele, G. Wilke, J. H. Campbell, and K. Takeuchi, "Effects of OH content, water vapor pressure, and temperature on slow crack growth behavior in phosphate laser glass", J. Non-Cryst. Solids, 263/264 (2000), p. 213-227.

[27] P. R. Ehrmann, J. H. Campbell, T. I. Suratwala, J. S. Hayden, D. Krashkevich, K. Takeuchi, "Optical loss and $\mathrm{Nd}^{3+}$ non-radiative relaxation by transition metal and rare earth ion impurities in phosphate laser glasses", J. NonCryst. Solids, 263/264, (2000) p. 251-262.

[28] J. S. Hayden, A. J. Marker III, T. I. Suratwala and J. H. Campbell, "Surface tensile layer generation in phosphate glass", J. Non-Cryst. Solids, 263/264 (2000), p. 228-239.

[29] S. Crichton, M. Tomozawa, J. Hayden, T. Suratwala, J. Campbell, "Sub-critical crack growth in a phosphate laser glass,"J. Am. Ceram. Soc. 82(11), 3097-104 (1999).

[30] C. B. Thorsness, T.I. Suratwala, R.A. Steele, J. H. Campbell, J. S. Hayden, S. A. Pucilowski, K. Suzuki, "Dehydroxylation of phosphate laser glass", SPIE Proceedings, 4102 (2000) p175-194.

[31] J. H. Campbell, E. P. Wallerstein, J. S. Hayden, D. L. Sapak, D. E. Warrington, A. J. Marker, H. Toratani, H. Meissner, S. Nakajima and T. Izumitani, "Elimination of platinum inclusions in phosphate laser glasses", Lawrence Livermore National Laboratory Report UCRL-53932, 1989.

[32] J. H. Campbell, E. P. Wallerstein, J. S. Hayden, D. L. Sapak, D. E. Warrington, A. J. Marker, “Effects of melting conditions on platinum-inclusion content in phosphate laser glasses", Glastech. Ber. Glass Sci. Technol., 68 (1995), p. 11.

[33] J. H. Campbell, E. P. Wallerstein, H. Toratani, H. E. Meissner, S. Nakajima and T. S. Izumitani, "Effects of process gas environment on platinum-inclusion density and dissolution rate in phosphate laser glasses", Glastech. Ber. Glass Sci. Technol., 68 (1995), p. 59.

[34] J. H. Campbell, "Modeling platinum inclusion dissolution in phosphate laser glasses", Glastech. Ber. Glass Sci. Technol., 68 (1995) p. 96.

[35] J. H. Campbell, T. I. Suratwala, C. B. Thorsness, J. S. Hayden, A. J. Thorne, J. M. Cimino, A. J. Marker III, K. Takeuchi, M. Smolley, and G. F. Ficini-Dorn, "Continuous melting of phosphate laser glasses", J. Non-Cryst Solids, 263\&264 (2000) p. 342-357.

[36] D. Golini, W. I. Kordonski, P. Dumas and S. Hogan, "Magnetorheological finishing (MRF) in commercial precision optics manufacturing", SPIE Proceedings, Vol. 3782 (1999), p. 80-91.

[37] C. J. Stolz, J. A. Menapace, M. R. Borden, A. Slomba, C. Kiikka and S. Gelman, "Status of optical finishing for the National Ignition Facility", in Optical Fabrication and Testing, OSA Technical Digest (2002), p. 67-69.

[38] J. J. DeYoreo, A. K. Burnham, and P. K. Whitman, "Developing $\mathrm{KH}_{2} \mathrm{PO}_{4}$ and $\mathrm{KD}_{2} \mathrm{PO}_{4}$ crystals for the world's most power laser", International Materials Review 47 (2002) p. 113-152.

[39] N. Zaitseva and L. Carman, "Rapid growth of KDP-type crystals," Prog. Cryst. Growth Charact. Mater. 43, 1-118 (2001).

[40] N. Zaitseva, J. Atherton, R. Rozsa, L. Carman, I. Smolsky, M. Runkel, R. Ryon, and L. James, "Design and benefits of continuous filtration in rapid growth of large KDP and DKDP crystals," J. Cryst. Growth 000, 1-10 (1999).

[41] J. J. De Yoreo, T. A. Land, and J. D. Lee, "Limits on surface vicinality and growth rate due to hollow dislocation cores on KDP $\{101\}, "$ Am. Phys. Soc. 78, 4462-4465 (1997).

[42] J. J. De Yoreo, T. A. Land, and B. Dair, "Growth morphology of vicinal hillocks on the $\{101\}$ face of $\mathrm{KH}_{2} \mathrm{PO}_{4}$ : From step-flow to layer-by-layer growth," Am. Phys. Soc. 73, 838-841 (1994).

[43] H. F. Robey and S. Y. Potapenko, "Ex situ microscopic observation of the laser instability of macrosteps on the surfaces of rapidly grown $\mathrm{KH}_{2} \mathrm{PO}_{4}$ crystals," J. Cryst. Growth 213, 355-367 (2000). 
[44] J. J. De Yoreo, T. A. Land, L. N. Rashkovich, T. A. Onischenko, J. D. Lee, O. V. Monovskii, N. P. Zaitseva, "The effect of dislocation cores on growth hillock vicinality and normal growth rates of KDP $\{101\}$ surfaces", J. Cryst. Growth 182, 442-460 (1997).

[45] J. J. De Yoreo, T. A. Land, and J. D. Lee, "Limits on surface vicinality and growth rate due to hollow dislocation cores on KDP \{101\}," Phys. Rev. Lett. 78, 4462-4465 (1997).

[46] T. A. Land, J. J. DeYoreo, T. L. Martin, and G. T. Palmore, "A comparison of growth hillock structure and step dynamics on KDP $\{100\}$ and $\{101\}$ surfaces using force microscopy”, Crystallography Reports, Vol. 44, No. 4, 704-716 (1999).

[47] C. J. Stolz, J. A. Menapace, F. Y. Génin, P. R. Ehrmann, P. E. Miller, and G. T. Rogowski, "Influence of BK7 substrate solarization on the performance of hafnia and silica multilayer mirrors," in Laser-Induced Damage in Optical Materials: 2002, G. J. Exarhos, A. H. Guenther, K. L. Lewis, N. Kaiser, M. J. Soileau, and C. J. Stolz, eds., Proc. SPIE 4932, 38-47, (2003).

[48] Z. L. Wu, C. J. Stolz, S. C. Weakley, J. D. Hughes, and Q. Zhao, "Damage threshold prediction of hafnia -silica multilayer coatings by nondestructive evaluation of fluence-limiting defects," Applied Optics, Vol. 40, 18971906, (2001).

[49] J. Taniguchi, N. E. LeBarron, J. Howe, D. J Smith, C. J. Stolz, C. L. Weinzapfel, and J. F. Kimmons, "Functional damage thresholds of hafnia/silica coating designs for the NIF laser," in Laser-Induced Damage in Optical Materials: 2000, G. J. Exarhos, A. H. Guenther, M. R. Kozlowski, K. L. Lewis, and M. J. Soileau, eds., Proc. SPIE 4347, 109-117, (2001).

[50] C. J. Stolz, L. M. Sheehan, M. K. Von Gunten, R. P. Bevis, and D. Smith, "The advantages of evaporation of Hafnium in a reactive environment to manufacture high damage threshold multilayer coatings by electron-beam deposition," in Advances in Optical Interference Coatings, Claude Amra, Angus Macleod, Editors, Proc. SPIE 3738, 318-324, (1999).

[51] C. J. Stolz, F. Y. Genin, M. R. Kozlowski, and Z. L. Wu, "Engineering high-damage-threshold NIF polarizers and mirrors," Inertial Confinement Fusion Quarterly Report, Vol. 9, UCRL-LR-105821-99-2, 151-161, (1999)

[52] S. C. Weakley, C. J. Stolz, Z. L. Wu, R. P. Bevis, and M. K. Von Gunten, "Role of starting material composition in interfacial damage morphology of hafnia silica multilayer coatings," in Laser-Induced Damage in Optical Materials: 1998, G. J. Exarhos, A. H. Guenther, M. R. Kozlowski, K. L. Lewis, and M. J. Soileau, eds., Proc. SPIE 3578, 137-143, (1999).

[53] C. J. Stolz, L. M. Sheehan, S. M. Maricle, S. Schwartz, and J. Hue, "A study of laser conditioning methods of hafnia silica multilayer mirrors," in Laser-Induced Damage in Optical Materials: 1998, G. J. Exarhos, A. H. Guenther, M. R. Kozlowski, K. L. Lewis, and M. J. Soileau, eds., Proc. SPIE 3578, 144-152, (1999).

[54] C. J. Stolz, L. M. Sheehan, S. M. Maricle, S. Schwartz, M. R. Kozlowski, R. T. Jennings, and J. Hue, "Laser conditioning methods of hafnia silica multilayer mirrors," in High-Power Lasers, Santanu Basu, Editor, Proc. SPIE 3264, 105-112, (1998).

[55] S. Schwartz, R. T. Jennings, J. F. Kimmons, R. P. Mouser, C. L. Weinzapfel, M. R. Kozlowski, C. J. Stolz, and J. H. Campbell, "Vendor-based laser damage metrology equipment supporting the National Ignition Facility," in Solid State Lasers for Application to Inertial Confinement Fusion, W. Howard Lowdermilk, editor, Proc. SPIE 3492, 933-938, (1999).

[56] T. I. Suratwala, M. L. Hanna, P. K. Whitman, "Effect of humidity during spin coating of Stöber silica sols," $J$. Non-Cryst. Sol. (2004) in press.

[57] E. K. Wheeler, R. Fluck, B. Woods, and P. K. Whitman "Effect of Surface Degradation on Optical Performance of Potassium Dihydrogen Phosphate Optics," Applied Optics Vol 42(27), pp.5545-5550 (2003).

[58] E. K. Wheeler, P.K. Whitman, T.A. Land, J. De Yoreo, C. B. Thorsness, J. H. McWhirter, M. L. Hanna, E. L Miller, "Investigation of Etch Pits on KDP Crystals with Porous Sol-Gel Coatings," Appl Phys A, 74, 813-823 (2002), UCRL-JC-142455.

[59] I. M. Thomas, "Optical and environmentally protective coatings for KDP harmonic converter crystals," presented at the SPIE 1991 International Symposium, San Diego, Calif., July 21-26, 1991.

[60] J. K. Lawson, D. M. Aikens, R. E. English, Jr., and C. R. Wolfe, "Power spectral density specifications for highpower lasers", Proc. Soc. Photo-Opt. Instrum. Eng., 2775, 345 (1996).

[61] J. K. Lawson, D. M. Aikens, R. E. English, Jr., W. T. Whistler, W. House, M. A. Nichols, "Surface figure and roughness tolerances for NIF optics and the interpretation of the gradient, P-V wavefront, and RMS specifications," in Optical Manufacturing and Testing III, H. Philip Stahl, Editor, Proceedings of SPIE Vol. 3782, 510-517 (1999). 
[62] W.H. Williams, "NIF large optics metrology software: description and algorithms" Lawrence Livermore National Laboratory Report UCRL-MA-137950, Mar. 16, 2000, p.1-39.

[63] J. H. Campbell, "Damage resistant optical glasses for high power lasers: A continuing glass science and technology challenge", Glass Sci. Technol. 75,C1 (2002) p.91-108.

[64] A. K. Burnham, L. Hackel, P. Wegner, T. Parham, L. Hrubesh, B. Penetrante, P. Whitman, S. Demos, J. Menapace, M. Runkel, M. Fluss, M. D. Feit, M. Key and T. Biesiada, "Improving 351-nm damage performance of large-aperture fused silica and DKDP optics", SPIE Proceedings, 4679 (2002) p. 173-185.

[65] J. H. Campbell, F. Rainer, M. Kozlowski, C. Wolfe, I. Thomas and F. Milanovich, "Damage resistant optics for a megajoule solid-state laser”, SPIE Proceedings, 1441 (1991), p. 444.

[66] J. H. Campbell and F. Rainer, "Optical glasses for high-peak-power applications”, SPIE Proceedings, 1761 (1992) p. 246-255.

[67] Proceedings from the annual meetings on "Laser-induced Damage in Optical Materials", 1971 to 2001, available from SPIE.

[68] J. Swain, S. Stokowski, D. Milam, and F. Rainer, "Improving the bulk laser damage resistance of potassium dihydrogen phosphate crystals by pulsed laser irradiation,” Appl. Phys. Lett. 40, 350-352 (1982).

[69] J. E. Swain, S. E. Stokowski, D. Milam, and G. Kennedy, "The effect of baking and pulsed laser irradiation on the bulk laser damage threshold of potassium dihydrogen phosphate crystals," Appl. Phys. Lett. 41, 12-14 (1982).

[70] M. Runkel, A. K. Burnham, D. Milam, W. Sell, M. D. Feit, and A. Rubenchik, "The results of pulse-scaling experiments on rapid-growth DKDP triplers using the Optical Sciences Laser at $351 \mathrm{~nm}$," in Laser-Induced Damage in Optical Materials: 2000, G. J. Exarhos, A. H. Guenther, M. R. Kozlowski, K. L. Lewis, and M. J. Soileau, eds., Proc. SPIE 4347, 359-372 (2001).

[71] M. Runkel and A. K. Burnham, "Differences in bulk damage probability distribution between tripler and z-cuts of KDP and DKDP at $355 \mathrm{~nm}$," in Laser-Induced Damage in Optical Materials: 2000, G. J. Exarhos, A. H. Guenther, M. R. Kozlowski, K. L. Lewis, and M. J. Soileau, eds., Proc. SPIE 4347, 408-419 (2001).

[72] A. K. Burnham, M. Runkel, M. D. Feit, A. M. Rubenchik, R. L. Floyd, T. A. Land, W. J. Siekhaus, and R. A. Hawley-Fedder, "Laser-induced damage in deuterated potassium dihydrogen phosphate," Appl. Opt. 42, 54835495 (2003).

[73] A. K. Burnham, M. Runkel, R. A. Hawley-Fedder, M. L. Carman, R. A. Torres, and P. K. Whitman, "Lowtemperature growth of DKDP for improving laser-induced damage resistance at $350 \mathrm{~nm}$," in Laser-Induced Damage in Optical Materials: 2000, G. J. Exarhos, A. H. Guenther, M. R. Kozlowski, K. L. Lewis, and M. J. Soileau, eds., Proc. SPIE 4347, 373-381 (2001).

[74] K. E. Montgomery and F. P. Milanovich, "High-laser-damage-threshold potassium dihydrogen phosphate crystals," J. Appl. Phys. 68, 3979-3982 (1990).

[75] L. J. Atherton, F. Rainer, J. J. DeYoreo, I. M. Thomas, N. Zaitseva and F. DeMarco, "Thermal and laser conditioning of production and rapid-growth KDP and KD*P crystals", SPIE Proceedings, Vol. 2114 (1994), p. 36-44.

[76] M. Runkel, K. Neeb, M. Staggs, J. Auerbach and A. Burnham, "The results of raster-scan laser conditioning studies on DKDP triplers using Nd:YAG and excimer lasers", SPIE Proceedings, Vol. 4679 (2002), p. 368-383.

[77] C. L. Battersby, L. M. Sheehan and M. R. Kozlowski, "Effects of wet etch processing on laser-induced damage of fused silica surfaces", SPIE Proceedings, Vol. 3578 (1999), p. 446-455.

[78] J. A. Menapace, B. Penetrante, D. Golini, A. Slomba, P. E. Miller, T. Parham, M. Nichols and J. Peterson, "Combined advanced finishing and UV laser conditioning for producing UV-damage-resistant fused silica optics", SPIE Proceedings, Vol. 4679 (2002), p. 56-68.

[79] R. M. Brusasco, B. M. Penetrante, J. E. Peterson, S. M. Maricle and J. Menapace, "UV laser conditioning for reduction of 351-nm damage initiation in fused silica", SPIE Proceedings, Vol. 4679 (2002), p. 48-55.

[80] R. M. Brusasco, B. M. Penetrante, J. A. Butler and L. W. Hrubesh, "Localized $\mathrm{CO}_{2}$ laser treatment for mitigation of 351-nm damage growth on fused silica", SPIE Proceedings, Vol. 4679 (2002), p. 40-47.

[81] R. R. Prasad, J. Bruere, J. Halpin, S. Mills and R. P. Hackel, "Design of a production facility to enhance optical damage resistance of $3 \omega$ optics", prepared for the 35th Symposium on Optical Materials for High Power Lasers, Boulder, Colorado, September 22-24, 2003.

[82] M. D. Feit and A. M. Rubenchik, "Mechanisms of $\mathrm{CO}_{2}$ laser mitigation of laser damage-growth in fused silica", SPIE 4932 (2003), p. 91-102. 
[83] M. A. Norton, L. W. Hrubesh, Z. Wu, E. Donohue, M. D. Feit, M. R. Kozlowski, D. Milam, K. P.Neeb, W. A. Molander, A. M. Rubenchik, W. D. Sell and P. Wegner, "Growth of laser initiated damage in fused silica at 351nm", SPIE Proceedings, Vol. 4347 (2001), p. 468.

[84] M. A. Norton, E. E. Donohue, W G. Hollingsworth, J. N. McElroy, R. P. Hackel, "Growth of Laser Initiated Damage in Fused Silica at $527 \mathrm{~nm}$ ", prepared for the 35th Symposium on Optical Materials for High Power Lasers, Boulder, Colorado, September 22-24, 2003.

[85] D. Golini, S. Jacobs, W. Kordonski and P. Dumas, "Precision optical fabrication using magnetorheological finishing", SPIE Proceedings: Critical Reviews of Optical Science and Technology, CR67-16 (1997), p. 251-253.

[86] A. B. Shorey, S. D. Jacobs, W. I. Kordonsky and R. F. Gans, "Experiments and observations regarding the mechanism of glass removal in magnetorheological finishing", Applied Optics, 40 (2001) p. 20-31.

[87] M. Kozlowski, C. Wolfe, M. Staggs and J. Campbell, "Large-area laser conditioning of dielectric thin film mirrors", SPIE Proceedings, Vol. 801 (1990), p. 376-392.

[88] C. J. Stolz, L. M. Sheehan, S. M. Maricle, S. Schwartz and J. Hue, "A study of laser conditioning methods of hafnia silica multilayer mirrors," in Laser-Induced Damage in Optical Materials: 1998, G. J. Exarhos, A. H. Guenther, M. R. Kozlowski, K. L. Lewis, and M. J. Soileau, eds., Proc. SPIE 3578, 144-152, (1999).

[89] C. J. Stolz, F. Y. Génin, M. R. Kozlowski, Z. L. Wu, "Engineering high-damage-threshold NIF polarizers and mirrors", Inertial Confinement Fusion Quarterly Report, Jan-Mar. 1999, Vol. 9, p. 151-162, Lawrence Livermore National Laboratory Report UCRL-LR-105821-99-2 (1999).

[90] J. Taniguchi, N. E. LeBarron, J. Howe, D. J. Smith, C. J. Stolz, C. L. Weinzapfel, and J. F. Kimmons, "Functional damage thresholds of hafnia/silica coating designs for the NIF laser," in Laser-Induced Damage in Optical Materials: 2000, G. J. Exarhos, A. H. Guenther, M. R. Kozlowski, K. L. Lewis, and M. J. Soileau, eds., Proc. SPIE 4347, 109-117, (2001).

[91] C. J. Stolz, L. M. Sheehan, S. M. Maricle, S. Schwartz, M. R. Kozlowski, R. T. Jennings, and J. Hue, "Laser conditioning methods of hafnia silica multilayer mirrors," in High-Power Lasers, Santanu Basu, Editor, Proc. SPIE 3264, 105-112, (1998).

[92] Z. L. Wu, C. J. Stolz, S. C. Weakley, J. D. Hughes, and Q. Zhao, "Damage threshold prediction of hafnia -silica multilayer coatings by nondestructive evaluation of fluence-limiting defects," Applied Optics, 40, 1897-1906, (2001).

[93] Z. L. Wu, C. J. Stolz, J. M. Yoshiyama, A. Salleo, "Characterization of fluence limiting defects in hafnia/silica multilayer coatings manufactured for the National Ignition Facility," in Optical Interference Coatings, Vol. 9, OSA Technical Digest Series, (Optical Society of America, Washington DC), pp. 247-249, (1998).

[94] C. J. Stolz, F. Y. Génin, and T. V. Pistor, "Electric-field enhancement by nodular defects in multilayer coatings irradiated at normal and 45 degree incidence," in Laser-Induced Damage in Optical Materials: 2003, G. J. Exarhos, A. H. Guenther, K. L. Lewis, N. Kaiser, M. J. Soileau, and C. J. Stolz, eds., Proc. SPIE, to be published.

[95] C. J. Stolz, J. M. Yoshiyama, Z. L. Wu, A. Salleo, J. Green, and R. Krupka, "Characterization of nodular and thermal defects in hafnia/silica multilayer coatings using optical, photothermal, and atomic force microscopy," in Laser-Induced Damage in Optical Materials: 1997, G. J. Exarhos, A. H. Guenther, M. R. Kozlowski, and M. J. Soileau, eds., Proc. SPIE 3244, 475-483, (1998).

[96] A. B. Papandrew, C. J. Stolz, Z. L. Wu, G. E. Loomis, S. Falabella, "Laser conditioning characterization and damage threshold prediction of hafnia/silica multilayer mirrors by photothermal microscopy," in Laser-Induced Damage in Optical Materials: 2000, G. J. Exarhos, A. H. Guenther, M. R. Kozlowski, K. L. Lewis, and M. J. Soileau, eds., Proc. SPIE 4347, 53-61, (2001).

[97] C. J. Stolz, F. Y. Génin, T. A. Reitter, N. E. Molau, R. P. Bevis, M. K. von Gunten, D. J. Smith, and J. F. Anzellotti, "Effect of $\mathrm{SiO}_{2}$ overcoat thickness on laser damage morphology of $\mathrm{HfO}_{2} / \mathrm{SiO}_{2}$ Brewster's angle polarizers at 1064 nm," in Laser-Induced Damage in Optical Materials: 1996, H. E. Bennett, A. H. Guenther, M. R. Kozlowski, B. E. Newnam, and M. J. Soileau, eds., Proc. SPIE 2966, 265-272, (1997).

[98] B. C. Stuart, M. D. Feit, A. M. Rubenchik, B. W. Shore and M. D. Perry, "Laser-induced damage in dielectrics with nanosecond to sub-picosecond pulses", Phys. Review Lett., 74 (1995) p. 2248-51.

[99] A. M. Rubenchik and M. D. Feit, "Initiation, growth and mitigation of UV laser-induced damage in fused silica", SPIE Proceedings, Vol. 4679 (2002), p. 79-95.

[100] M. D. Feit, A. M. Rubenchik, D. Faux, R. Riddle, D. Eder, B. Penetrante, D. Milam, F. Génin, M. Kozlowski, "Modeling of laser damage initiated by surface contamination", Proc. SPIE 2966 (1997), p. 417-424.

[101] M. Lenzner, J. Kruger, S. Sartania, Z. Cheng, C. Spielmann, G. Mourou, W. Kautek and F. Krausz, "Femtosecond optical breakdown in dielectrics", Phys. Rev. Lett., 80 (1998) p. 4076-4079. 
[102] W. Kautek, J. Kruger, M. Lenzner, S. Sartinia, C. Speilmann and F. Krausz, "Laser ablation of dielectrics with pulse durations between 20fs and 3ps", Appl. Phys. Lett., 69 (1996) 3146-3148.

[103] M. D. Feit and A.M. Rubenchik, "Implications of nanoabsorber initiators for damage probability curves, pulselength scaling and laser conditioning", prepared for the 35th Symposium on Optical Materials for High Power Lasers, Boulder, Colorado, September 22-24, 2003.

[104] M. Nostrand, T. Weiland, R. Luthi, J. Vickers, W. Sell, J. Stanley, J. Honig, J. Auerbach, R. Hackel, P. Wegner, "A large aperture, high energy laser system for optics and optical component testing", prepared for the 35th Symposium on Optical Materials for High Power Lasers, Boulder, Colorado, September 22-24, 2003.

[105] L. M. Sheehan, M. R. Kozlowski, C. J. Stolz, F. Y. Génin, M. Runkel, S. Schwartz, and J. Hue, "Large area damage testing of optics," in Specification, Production, and Testing of Optical Components and System, Gee, Anthony E.; Houee, Jean, eds., Proc. SPIE 2775, 357-369, (1996).

[106] M. C. Nostrand, S. Thompson, W. Siekhaus, M. Fluss, D. Hahn, P. Whitman, A. Burnham, "Identification and elimination of fluorescent surface-damage precursors on DKDP optics," Laser-Induced Damage in Optical Materials: 2002, SPIE Vol. 4932, 192-201 (2003).

[107] S. Schwartz, R. T. Jennings, J. F. Kimmons, R. P. Mouser, C. L. Weinzapfel, M. R. Kozlowski, C. J. Stolz and J. H. Campbell, "Vendor-based laser damage metrology equipment supporting the National Ignition Facility," in Solid State Lasers for Application to Inertial Confinement Fusion, W. Howard Lowdermilk, editor, Proc. SPIE 3492, 933-938, (1999).

[108] M. R. Kozlowski, J. Carr, I. Hutcheon, R. Torres, L. Sheehan, D. Camp and M. Yan, "Depth profiling of polishing-induced contamination on fused silica surfaces", SPIE Proceedings, 3244 (1998), p. 365-375.

[109] L. M. Sheehan, M. R. Kozlowski and D. W. Camp, "Application of total reflection microscopy for laser damage studies on fused silica”, SPIE Proceedings, 3244 (1998), p. 282-295.

[110] S. G. Demos, M. C. Nostrand, M. Staggs, C. W. Carr, D. Hahn, M. R. Kozlowski, L. Sheehan, C. Battersby and A. Burnham, "Investigation of fluorescence microscopy as a tool for noninvasive detection and imaging of damage precursors at 351-nm", SPIE Proceedings, 4679 (2002), p. 347-359.

[111] Z. Wu, M. Thomsen, P. K. Kuo, Y. S. Lu, C. J. Stolz and M. R. Kozlowski, "Photothermal characterization of optical thin film coatings," Opt. Eng. 36 (1997).

[112] C. J. Stolz, D. J. Chinn, R. D. Huber, C. L. Weinzapfel, and Z. L. Wu, "Photothermal multi-pixel imaging microscope," in Laser-Induced Damage in Optical Materials: 2003, G. J. Exarhos, A. H. Guenther, K. L. Lewis, N. Kaiser, M. J. Soileau, and C. J. Stolz, eds., Proc. SPIE, to be published.

[113] M.D. Feit, A.M. Rubenchik, M.R. Kozlowski, F.Y. Génin, S. Schwartz and L.M. Sheehan," Extrapolation of damage test data to predict performance of large-area NIF optics at $355 \mathrm{~nm}$ " SPIE 3578, 226-31 (1999).

[114] S. Schwartz, M.D. Feit, M.R. Kozlowski and R.P. Mouser, "Current $3 \omega$ large optic test procedures and data analysis for the quality assurance of National Ignition Facility optics", SPIE 3578, 314-21 (1999). 